\title{
Secretion of the chemokine interleukin-8 during Japanese encephalitis virus infection
}

\author{
ADITI SINGH, RAJESH KULSHRESHTHA and ASHA MATHUR \\ Postgraduate Department of Microbiology, KG Medical College, Lucknow 226003, India
}

\begin{abstract}
Japanese encephalitis (JE) virus infection induces infiltration of neutrophils in neural as well as extraneural tissues in patients. As interleukin-8 (IL-8) has inflammatory properties, the present study was undertaken to investigate the IL-8 concentrations in cerebrospinal fluid (CSF) and serum from patients with JE and correlate them with neutrophil counts. IL-8 was measured in the CSF or serum of 30 patients with confirmed JE. The majority $(92 \%)$ of the acute CSF samples showed raised levels of IL8 with raised numbers of polymorphonuclear leucocytes. Similarly, significantly higher serum IL-8 concentrations were detected in the acute phase of illness than in convalescent JE patients or normal healthy controls. Twenty-one of 25 patients with high concentrations of IL-8 showed significantly increased neutrophil counts in acute phase sera. A gradual decline in neutrophil counts was observed in the convalescent phase of patients who recovered. There was a significant correlation between IL-8 level and the severity of illness, as all severely ill and fatal cases showed higher levels of IL-8 in acute CSF or serum than the levels found in those who recovered. IL-8 concentrations remained high for a longer period in patients with prolonged severe illness than in those who made a complete recovery.
\end{abstract}

\section{Introduction}

Japanese encephalitis (JE) is an acute viral zoonotic infection that commonly affects children and is a major cause of acute encephalopathy in India [1]. After entry into the host, JE virus (JEV) induces a polymorphonuclear leucocytosis with variable effects on different components of peripheral blood leucocytes [2], replicates in a number of organs and generates a rapid inflammatory response [3]. In JEV infection, the inflammatory cells predominantly consist of $\mathrm{T}$ lymphocytes, macrophages and neutrophils [3, 4]. JEV targets the central nervous system (CNS), clinically manifesting with fever, headache, vomiting, signs of meningeal irritation and altered consciousness leading to high mortality and neurological sequelae in some of those who survive [1]. An earlier study demonstrated that, in mice, JEV induces a neutrophil leucocytosis [5]

Received 23 Feb. 1999; revised version accepted 1 Dec. 1999.

Corresponding author: Dr A. Mathur (e-mail: chauhan_alok @hotmail.com). and activates neutrophil metabolism to degrade the phagocytosed JE viral protein and nucleic acid [6].

The inflammatory response observed within the CNS in aseptic meningitis or viral encephalitis is mediated by chemotactic cytokines or chemokines, which are released by various cells of the CNS. The inflammation results in an increased level of these cytokines in the cerebrospinal fluid (CSF) [7]. Chemokines fall into four categories which are defined by a cysteine motif: $\mathrm{CXC}, \mathrm{CC}, \mathrm{C}$ and $\mathrm{CX}_{3} \mathrm{C}-$ where $\mathrm{C}$ is cysteine and $\mathrm{X}$ is any amino-acid residue [8]. They appear to play a protective role or initiate an irreversible immune response leading to cell death [9]. The CXC chemokine subfamily includes interleukin-8 (IL-8), which regulates selective chemotaxis, degranulation, activation of neutrophils [10] and neutrophil adhesion to endothelial cells [11]. Van Deuren et al. [12] have shown a correlation between production of pro-inflammatory cytokines, including IL-8, and the severity of disease in meningococcal infections. As IL-8 is an important mediator of neutrophil recruitment and JE infection is known to cause leucocytosis with neutrophilia, the present study examined IL-8 levels in the CSF and in the acute and convalescent phase sera of confirmed JE patients. 


\section{Materials and methods}

Study group

Sixty-nine patients (aged 3-20 years) admitted with acute encephalopathic illness (acute, non-transient alteration of consciousness with or without fever, or other neurological symptoms) at GM and Associated Hospital, Lucknow and Sanjay Gandhi Postgraduate Institute of Medical Sciences, Lucknow from July 1997 to March 1998 were the subjects of the present study. The duration of illness on admission was $<5$ days. JEV infection was confirmed by isolation and identification of the virus from CSF, or by its detection in CSF cells by the indirect immunofluorescence technique [13], or by measuring JEV-specific IgM antibody, or by a four-fold or greater rise in JEV-specific HAI antibody titre in the serum [14]. The acute stage sera were collected on admission to hospital and convalescent phase sera were collected after a 2-week interval from those patients whose parents agreed to participate in the study. The study included 30 patients in whom JEV infection was confirmed. Seven patients died within a week of admission, six showed prolonged illness and 17 recovered completely. The control group consisted of serum samples from 27 normal healthy individuals of matching age and sex, and CSF samples from 10 patients with symptoms other than acute encephalitis.

\section{Assessment of the severity of disease}

A proforma-directed history was taken and examination was performed on admission. A careful record of each patient's progress in hospital was maintained. Evaluation of the severity of disease was based on the staging of altered sensorium, a modification from the classification of progressive cerebral dysfunction of Plum and Posner [15]: grade I, drowsy but responsive to voice commands; grade II, unresponsive to voice but responsive to pain (light coma); and grade III, unresponsive to pain (deep coma). Prolonged illness was defined as those patients in whom coma and other neurological manifestations persisted and the patients needed hospitalisation for $\geqslant 3$ weeks.

\section{Animals}

Suckling Swiss albino mice (1-2 days old) obtained from the mouse colony maintained in this department were used for isolation of virus.

\section{Serological study}

The titres of JEV-specific HAI antibodies in the sera of patients were estimated by microtitration assay as described previously [14]. A four-fold or greater rise in antibody titre was considered positive. The JEV-specific IgM antibodies in blood were measured by antibody capture ELISA [14].

\section{CSF examination}

CSF samples were collected in sterile containers by lumbar puncture at the time of admission and immediately transferred to the laboratory. The CSF was centrifuged and the cell pellet was collected. Smears were prepared and differential leucocyte counts were made visually on smears stained by Leishman's stain.

\section{Determination of IL-8 in CSF or serum}

The quantitative determination of human IL-8 in the acute CSF or acute and convalescent phase sera of patients with confirmed JE was performed with an IL-8 enzyme immunoassay kit (Immunotech, Marseille, France). The assay was a sandwich-type ELISA to capture IL-8. The intensity of the colour produced is proportional to the IL-8 concentration in the sample. The results of the unknown samples were calculated by interpolation from a standard curve generated with control samples assayed in the same assay as the sample. The values were expressed as $\mathrm{pg} / \mathrm{ml}$. A cut-off value of $50 \mathrm{pg} / \mathrm{ml}$ was chosen as the upper limit of normal values. The minimum detectable concentration of IL- 8 was $8 \mathrm{pg} / \mathrm{ml}$ in plasma. The intra- and interassay coefficients of variation were $\pm 2.3 \%$ and $\pm 7.6 \%$, respectively. There were no cross-reactions with IL- $1 \alpha$, IL-1 $\beta$, IL-3, IL-4, IL-5, IL-6, IL-7, IL-10, GM-CSF, M-CSF, G-CSF, PF4 and $\beta$-thromboglobulin as specified in the instruction protocol by the manufacturer.

\section{Statistical analysis}

Data were analysed by Student's $t$ test; $\mathrm{p}<0.05$ was considered significant.

\section{Results}

\section{Study group}

A total of 30 patients with confirmed JE was included in the study (Table 1). The CSF showed marked leucocytosis (241 SD 15 cells $/ \mu \mathrm{l}$ ) in $92 \%$ of $\mathrm{JE}$ patients, which was significantly $(\mathrm{p}<0.0001)$ higher than in controls ( $5 \mathrm{SD} 0.2$ cells $/ \mu \mathrm{l}$ ). It was observed that JEV infection induced neutrophil leucocytosis in the early phase of the illness. The maximum neutrophil count was $70 \mathrm{SD} 1.2 \%$ of the total count (mean neutrophil count 47 SD 1\%). After the fifth day of illness, a greater percentage of CSF cells was made up of mononuclear cells (mean lymphocyte count 82 SD 2\%) (Fig. 1).

\section{IL-8 levels in CSF}

The CSF samples from 30 patients with confirmed JE and 10 controls were evaluated for IL-8 levels. In the 
Table 1. Results obtained from CSF and serum from 30 patients with confirmed JE

\begin{tabular}{|c|c|c|c|c|c|}
\hline \multirow{3}{*}{$\begin{array}{l}\text { Subject } \\
\text { no. }\end{array}$} & \multicolumn{2}{|c|}{ Acute phase CSF } & \multirow{3}{*}{$\begin{array}{l}\text { IgM AC- } \\
\text { ELISA }\end{array}$} & \multirow{2}{*}{\multicolumn{2}{|c|}{ Serum HAI antibody titre }} \\
\hline & \multirow{2}{*}{$\begin{array}{l}\text { Virus } \\
\text { isolation }\end{array}$} & \multirow{2}{*}{$\begin{array}{l}\text { Immuno- } \\
\text { fluorescence }\end{array}$} & & & \\
\hline & & & & Acute & Convalescent \\
\hline 1 & - & - & + & 80 & 1280 \\
\hline 2 & - & - & + & 20 & 320 \\
\hline 3 & - & - & + & 80 & 640 \\
\hline 4 & - & - & + & 160 & 640 \\
\hline 5 & - & - & + & 80 & 1280 \\
\hline 6 & - & - & + & 20 & 320 \\
\hline 7 & - & - & + & 80 & 640 \\
\hline 8 & - & - & + & 20 & 80 \\
\hline 9 & + & + & - & 80 & Died \\
\hline 10 & - & - & - & 20 & 160 \\
\hline 11 & - & - & + & $<10$ & 640 \\
\hline 12 & + & + & - & $<10$ & Died \\
\hline 13 & - & - & + & $<10$ & 80 \\
\hline 14 & - & - & + & $<10$ & 80 \\
\hline 15 & - & - & + & 20 & 80 \\
\hline 16 & - & - & - & 20 & 1280 \\
\hline 17 & - & - & + & 10 & 160 \\
\hline 18 & - & - & + & $<10$ & 640 \\
\hline 19 & + & + & - & $<10$ & Died \\
\hline 20 & - & - & + & 20 & 320 \\
\hline 21 & - & - & + & 320 & 1280 \\
\hline 22 & + & + & - & 80 & Died \\
\hline 23 & - & - & - & 80 & 1280 \\
\hline 24 & - & - & + & 80 & 1280 \\
\hline 25 & - & - & + & 20 & 320 \\
\hline 26 & - & - & + & 40 & 320 \\
\hline 27 & - & + & - & 20 & Died \\
\hline 28 & + & + & - & 80 & Died \\
\hline 29 & + & + & - & $<10$ & Died \\
\hline 30 & - & - & + & 160 & 640 \\
\hline
\end{tabular}

IgM AC-ELISA, IgM antibody-capture ELISA on serum.

Died, patient died before the collection of a second sample.

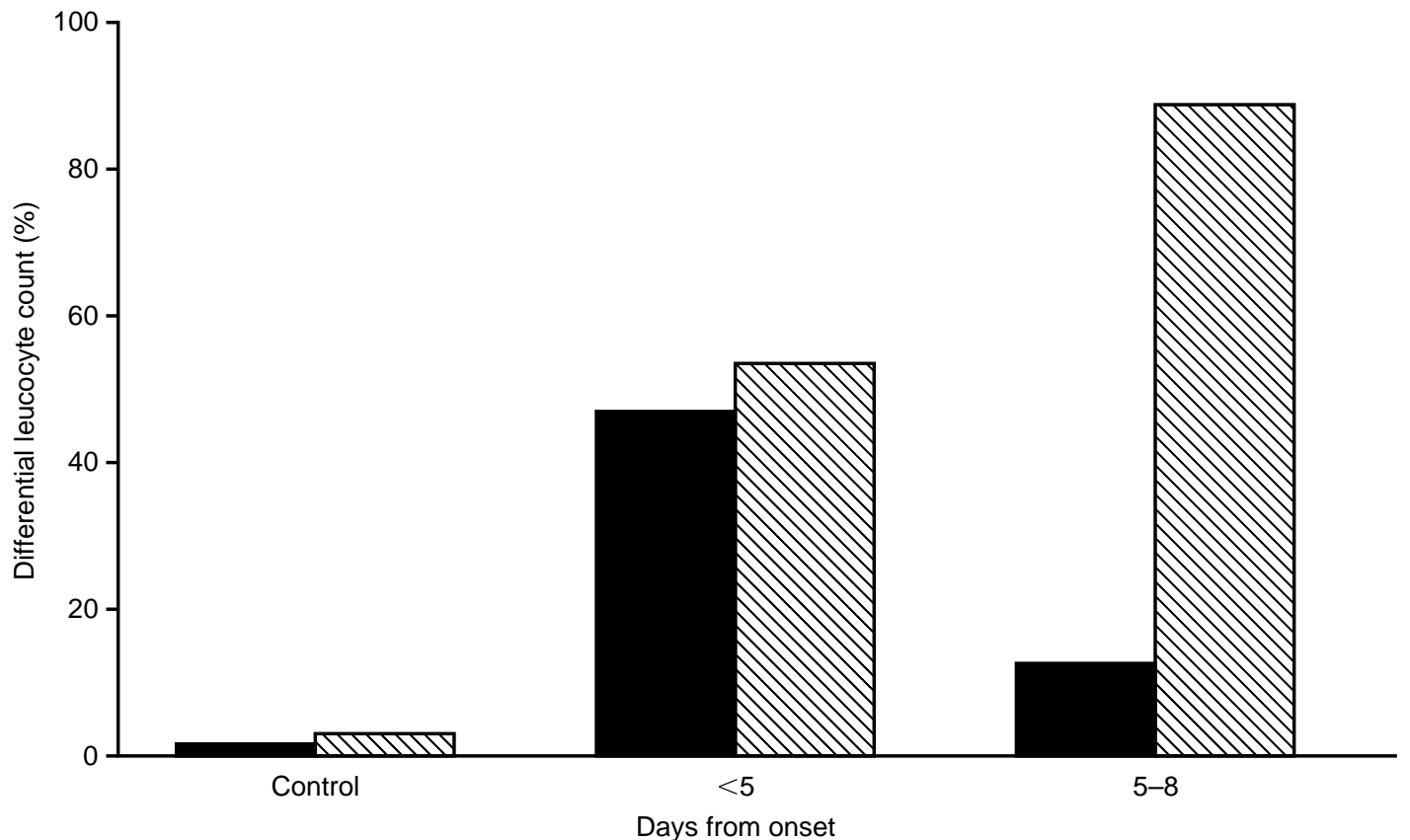

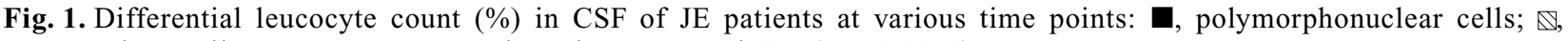
mononuclear cells. Data are expressed as the mean and SD $(p \leqslant 0.0001)$.

majority (92\%) of JE patients, CSF showed significantly greater levels of IL-8 - mean 846.75 (SD 259.56) $\mathrm{pg} / \mathrm{ml}$ - than controls - mean 35.85 (SD 10.8) $\mathrm{pg} / \mathrm{ml}(\mathrm{p}<0.001)$. Furthermore, there was a significant difference between the levels of IL- 8 in JE patients who died or had prolonged illness and in patients who recovered $(p<0.01)$ or in controls $(p<0.0001)$ (Fig. 2a). 
a

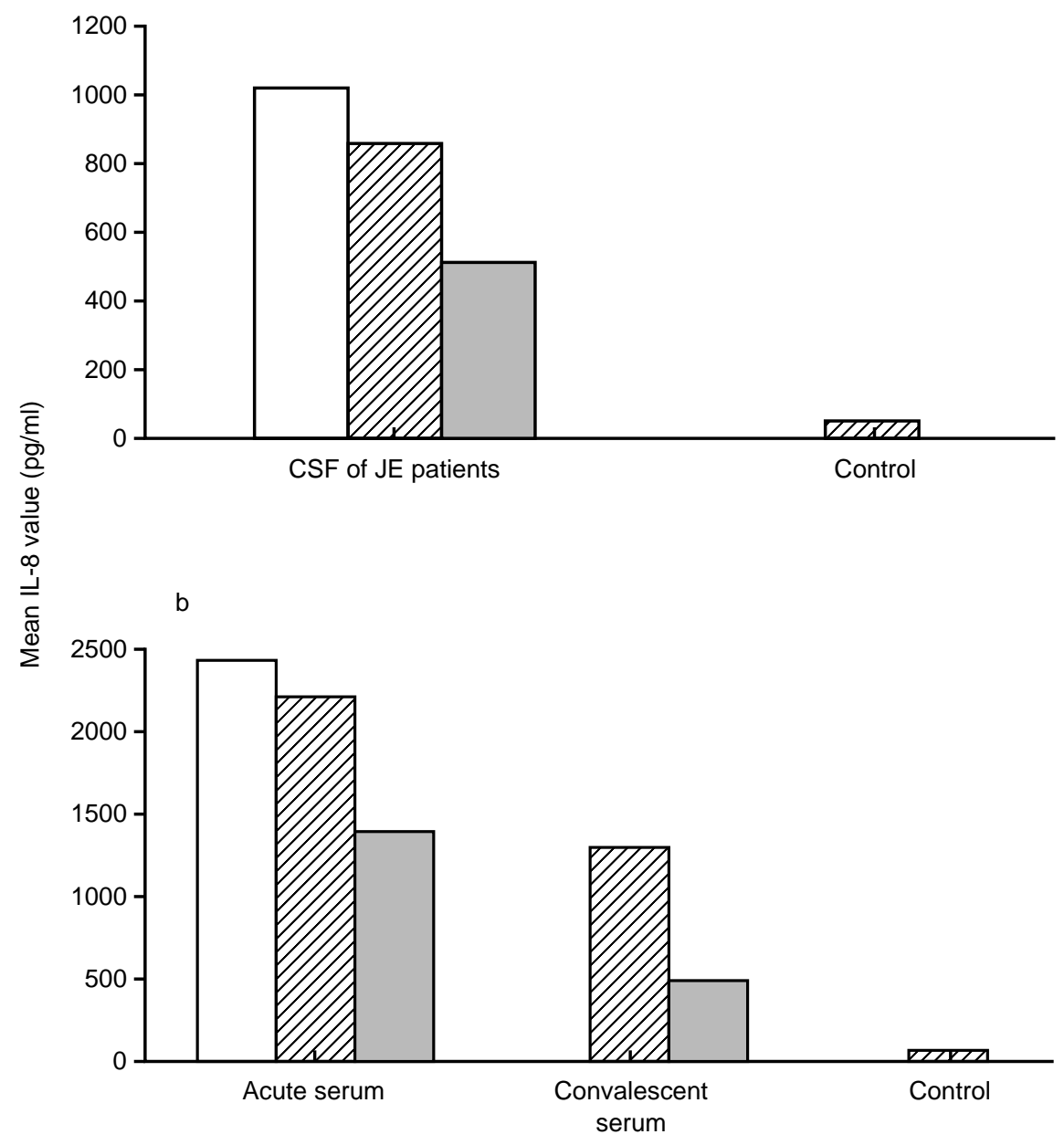

Fig. 2. IL-8 levels in (a) CSF and (b) serum from patients with JEV infection: fatal cases ( $\square$ ), patients with prolonged illness $(\mathbb{Z})$ and patients who recovered completely $(\square)$. Controls consisted of CSF $(\mathbb{Z})$ from patients with symptoms other than acute encephalitis and serum $(\mathbb{Z})$ from normal healthy individuals. Data are expressed as mean and SD.

\section{Correlation between neutrophil counts and $I L-8$ levels in CSF}

Elevated levels of IL- 8 in the acute CSF correlated with high neutrophil counts as well as with severe illness (Table 2).

\section{IL-8 levels in serum of JE patients}

The IL- 8 level was measured in 30 acute phase sera, 23 convalescent phase sera from JE confirmed patients and 27 serum samples from normal healthy individuals.
The IL-8 level in acute phase sera was significantly elevated - 1415 (SD 933.9) pg/ml - compared with that in the convalescent phase -817.04 (SD 510.12) $\mathrm{pg} / \mathrm{ml}(\mathrm{p}<0.05)$ - or controls - 25.97 (SD 2.23) $\mathrm{pg} / \mathrm{ml}(\mathrm{p}<0.0001)$. There was a significant correlation between IL- 8 values in the sera and the severity of clinical illness. The values were higher in acute serum samples from 7 of 30 patients who died and 6 of 30 severely ill patients than in samples from 12 cases who showed complete recovery $(p<0.001)$ (Fig. 2b). Circulating IL-8 could not be detected in 5 of 30 acute serum samples. IL- 8 levels remained high in the

Table 2. Correlation of IL-8 levels and neutrophil counts with the severity of illness in the acute CSF of patients with confirmed JE

\begin{tabular}{lcc}
\hline Grade of illness & Mean (SD) IL-8 $(\mathrm{pg} / \mathrm{ml})$ & $\begin{array}{c}\text { Mean (SD) neutrophil } \\
\text { count }(\%)\end{array}$ \\
\hline I & $546.22(325.4)$ & $29(1.6)^{*}$ \\
II & $859.75(458.61)$ & $43(1.1)$ \\
III & $1128.43(598.11)$ & $61(2.1)$ \\
Control & $35.85(10.80)$ & $2(0.01)^{\dagger}$ \\
\hline${ }^{*} \mathrm{p}<0.05$. & & \\
${ }^{\dagger} \mathrm{p}<0.001$. & &
\end{tabular}


second sample of five of six severely ill patients $(83.3 \%)$, with a mean value of 1261.72 (SD 822.71) $\mathrm{pg} / \mathrm{ml}$ as compared with the levels in patients who recovered - 464.33 (SD 325.7) $\mathrm{pg} / \mathrm{ml}$.

\section{Relationship between IL-8 levels and neutrophil counts}

Fig. 3 shows a significant correlation between IL-8 levels and neutrophil counts in the acute phase sera of JE patients $(p<0.001)$. Convalescent phase sera of patients who had recovered showed a gradual decline in neutrophil counts. Twenty-one of the 25 samples with high IL-8 concentrations in the acute phase showed significantly increased peripheral blood neutrophil counts with the highest level of IL-8 $(3141.0 \mathrm{pg} / \mathrm{ml})$ in the patient who had $85 \%$ neutrophils in the total peripheral leucocyte count.

\section{Discussion}

After haematogenous spread in the host, JEV replicates in a number of organs and generates a rapid inflammatory response $[3,4]$. However, the mechanism involved in producing this inflammatory state is not clearly understood. IL-8, a chemotactic cytokine, has inflammatory and growth-regulating properties. It recruits neutrophils to the brain parenchyma [16] and is a potent chemo-attractant and activator of neutrophils [17]. The present study showed very high concentrations of IL-8 in CSF during the acute stage of the illness in the majority of the patients with JE, which corresponded with the degree of severity of the disease. Although a transient increase in the level of IL-8 in
CSF has been observed in patients with viral aseptic meningitis [18], bacterial pyogenic meningitis [7] or self-resolving aseptic meningitis [19], its role in viral encephalitis is not clear.

The present study found a significant relationship between IL-8 levels and neutrophil counts in CSF and the severity of illness in patients with JE. In severely ill patients (grades III and II), the CSF showed raised neutrophil counts as well as high IL-8 levels, as compared with the patients who made a complete recovery (grade I). Previous studies have demonstrated that JEV initiates a rapid inflammatory response with mononuclear and polymorphonuclear cell infiltration of the brain $[3,4]$ and pleocytosis with increased neutrophils in the CSF of patients with JE [20].

This is the first report describing IL- 8 release in the CSF in JE. The source of IL- 8 in CSF is likely to be multicellular. IL-8 protein or mRNA expression, or both, in the CNS by endothelial cells, microglia, the resident macrophage of brain [21], astrocytes [22] and glioblastoma cell lines in response to IL- $1 \beta$ and TNF- $\alpha$ have been identified. This production could be inhibited by pre-treatment of microglia by antiinflammatory cytokines, i.e., IL-4, IL-10 or TGF- $\beta$. Ishiguro and his co-workers [7] have also shown the production of IL-8 in CSF during meningitis in children. IL-8 induces chemotaxis of neutrophils, releases intracellular enzymes from neutrophils and up-regulates cell adhesion molecules, potentially aiding leucocyte trafficking across the blood-brain barrier (BBB) [23]. Once neutrophils have crossed the BBB, it induces degranulation of neutrophils to release chemoattractants for $\mathrm{T}$ lymphocytes [24] and primes them for

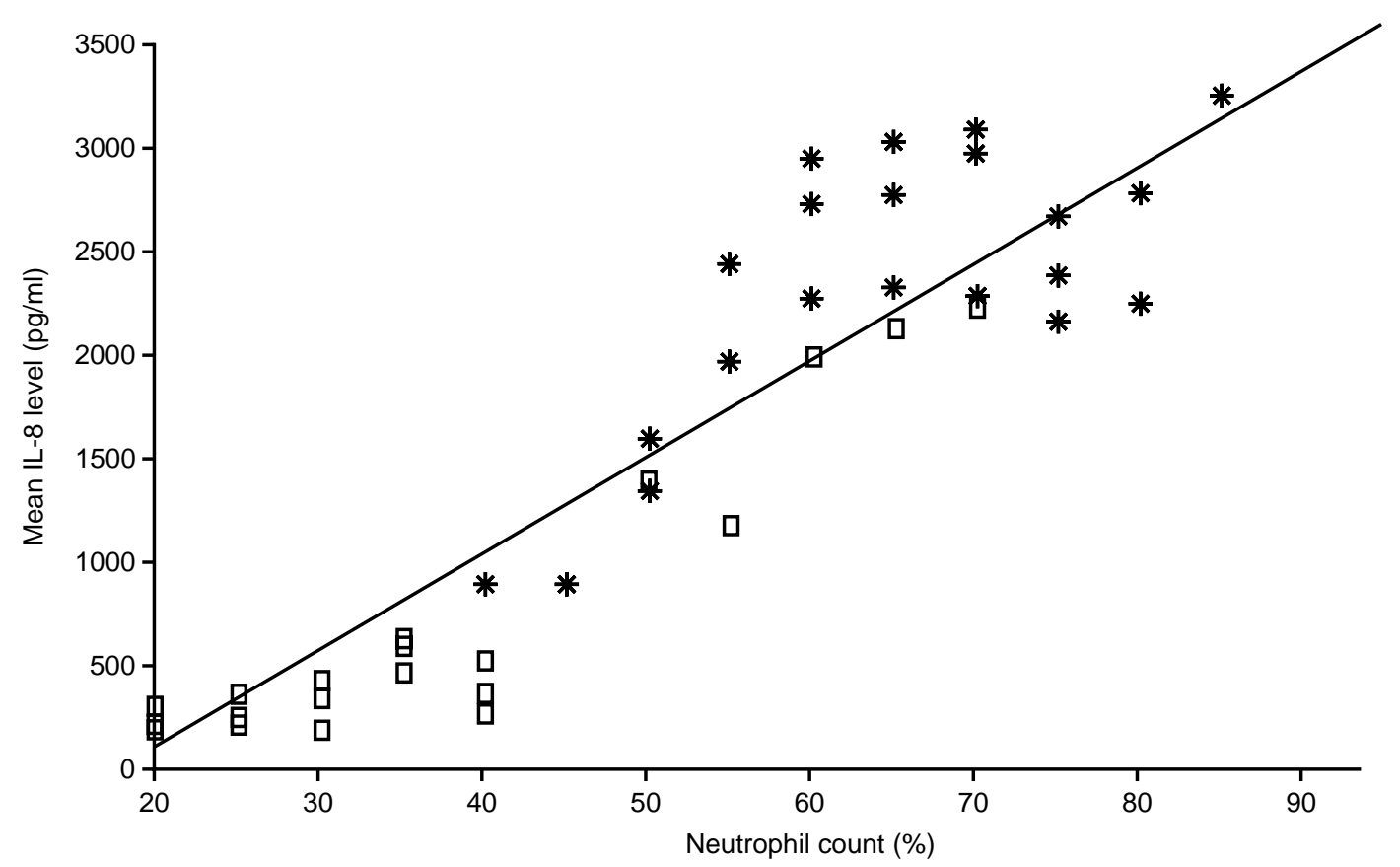

Fig. 3. Relationship between IL-8 levels and neutrophil counts in acute $(*)$ and convalescent $(\square)$ sera of patients with JE $(p \leqslant 0.001)$. 
superoxide production [25]. Thus, an excess of activated neutrophils may have a detrimental effect and regulation of IL- 8 chemotactic activity may be necessary to reduce the negative effects of neutrophil influx.

In this study, JEV significantly increased serum levels of IL-8 during the acute stage of illness as compared with the convalescent stage. The level of IL-8 was dependent on the severity of disease, as in convalescent phase serum it declined markedly in patients who recovered completely whereas it remained high in patients with prolonged severe illness. All acute samples had significantly increased levels of IL-8 in fatally ill as well as in severely ill patients. This difference may be due to the response of the cells synthesising IL-8 to JEV. The present study showed a good correlation between IL-8 and neutrophil counts in patients with JE. Many pro-inflammatory cytokines, including IL-8, have been shown before neutrophil influx, e.g., during bacterial meningitis [19] and pregnancy [26]. The role of neutrophils in providing the first line of defence against bacterial infections is clear [27]. A recent study demonstrated the ability of neutrophils to degrade phagocytosed JEV, via triggering the respiratory burst and the generation of toxic oxygen radicals [6].

The interactions between monocytes/macrophages, IL-8 and neutrophils appear to be important in understanding the pathogenesis of inflammatory lesions in JE. Studies in vitro have shown that IL-8 can enhance the growth of astrocytes and microglia, which are major immunocompetent cells in the nervous system [28]. In conclusion, the data show that IL-8 plays an important role in inflammatory responses involving insults to the brain. Studies are in progress to determine the precise pathophysiological role of IL-8 during JEV infection.

\section{References}

1. Kumar R, Mathur A, Kumar A, Sethi GD, Sharma S, Chaturvedi UC. Virological investigations of acute encephalopathy in India. Arch Dis Child 1990; 65: 1227-1230.

2. Chaturvedi UC, Mathur A, Tandon P, Natu SM, Rajvanshi S, Tandon HO. Variable effect on peripheral blood leucocytes during JE virus infection of man. Clin Exp Immunol 1979; 38: 492-498.

3. Mathur A, Bharadwaj M, Kulshreshtha R, Rawat S, Jain A, Chaturvedi UC. Immunopathological study of spleen during Japanese encephalitis virus infection in mice. Br J Exp Pathol 1988; 69: 423-432.

4. Johnson RT, Burke DS, Elwell M et al. Japanese encephalitis: immunocytochemical studies of viral antigen and inflammatory cells in fatal cases. Ann Neurol 1985; 18: 567-573.

5. Mathur A, Khanna N, Chaturvedi UC. Breakdown of bloodbrain barrier by virus-induced cytokine during Japanese encephalitis virus infection. Int $J$ Exp Pathol 1992; 73: $603-611$.

6. Srivastava S, Khanna N, Saxena SK, Singh A, Mathur A, Dhole TN. Degradation of Japanese encephalitis virus by neutrophils. Int J Exp Pathol 1999; 80: 17-24.
7. Ishiguro A, Suzuki Y, Inaba Y et al. The production of IL-8 in cerebrospinal fluid in aseptic meningitis of children. Clin Exp Immunol 1997; 109: 426-430.

8. Bazan JF, Bacon KB, Hardiman G et al. A new class of membrane-bound chemokine with a $\mathrm{CX}_{3} \mathrm{C}$ motif. Nature 1997; 385: $640-644$.

9. McCracken GH, Saez-Llorens X. Contribution of cytokines to meningeal inflammation in bacterial meningitis. In: Peterson PK, Remington JS (eds) In defense of the brain: current concepts in the immunopathogenesis and clinical aspects of CNS infections. Boston, Blackwell Science. 1997: 107-123.

10. Kunkel SL, Lukacs NW, Strieter SM. The role of interleukin-8 in the infectious process. Ann NY Acad Sci 1994; 730: 134-143.

11. Baggiolini M, Clark-Lewis I. Interleukin-8, a chemotactic and inflammatory cytokine. FEBS Lett 1992; 307: 97-101.

12. van Deuren M, van der Ven-Jongekrijg J, Bartelink AKM, van Dalen R, Sauerwein RW, van der Meer JWM. Correlation between proinflammatory cytokines and anti-inflammatory mediators and the severity of disease in meningococcal infections. J Infect Dis 1995; 172: 433-439.

13. Mathur A, Kumar R, Sharma S, Kulshreshtha R, Kumar A, Chaturvedi UC. Rapid diagnosis of Japanese encephalitis by immunofluorescent examination of cerebrospinal fluid. Indian $J$ Med Res 1990; 91: 1-4.

14. Sharma S, Mathur A, Prakash V, Kulshreshtha R, Kumar R, Chaturvedi UC. Japanese encephalitis virus latency in peripheral blood lymphocytes and recurrence of infection in children. Clin Exp Immunol 1991; 85: 85-89.

15. Plum F, Posner JB. The diagnosis of stupor and coma, 2nd edn. Philadelphia, FA Davis. 1972: 56-67.

16. Bell MD, Taub DD, Perry VH. Overriding the brain's intrinsic resistance to leukocyte recruitment with intraparenchymal injections of recombinant chemokines. Neuroscience 1996; 74: $283-292$.

17. Harada A, Sekido N, Akahoshi T, Wada T, Mukaida N, Matsushima K. Essential involvement of interleukin-8 (IL-8) in acute inflammation. J Leukoc Biol 1994; 56: 559-564.

18. Koziel MJ, Dudley D, Afdhal N et al. HLA class 1-restricted cytotoxic $\mathrm{T}$ lymphocytes specific for hepatitis $\mathrm{C}$ virus. Identification of multiple epitopes and characterization of patterns of cytokine release. J Clin Invest 1995; 96: 23112321.

19. López-Cortés LF, Cruz-Ruiz M, Gómez-Mateos J, VicianaFernandez P, Martinez-Marcos FJ, Panchón J. Interleukin-8 in cerebrospinal fluid from patients with meningitis of different etiologies: Its possible role as neutrophil chemotactic factor. $J$ Infect Dis 1995; 172: 581-584.

20. Johnson RT, Intralawan P, Puapanwatton S. Japanese encephalitis: identification of inflammatory cells in cerebrospinal fluid. Ann Neurol 1986; 20: 691-695.

21. Ehrlich LC, Hu S, Sheng WS et al. Cytokine regulation of human microglial cell IL-8 production. J Immunol 1998; 160: 1944-1948.

22. Aloisi F, Carè A, Borsellino $\mathrm{G}$ et al. Production of hemolymphopoietic cytokines (IL-6, IL-8, colony-stimulating factors) by normal human astrocytes in response to IL- $1 \beta$ and tumor necrosis factor- $\alpha$. J Immunol 1992; 149: 2358-2366.

23. Adams DH, Lloyd AR. Chemokines: leukocyte recruitment and activation cytokines. Lancet 1997; 349: 490-495.

24. Taub DD, Anver M, Oppenheim JJ, Longo DL, Murphy WJ. T lymphocyte recruitment by interleukin-8 (IL-8): IL-8-induced degranulation of neutrophils releases potent chemoattractants for human $\mathrm{T}$ lymphocytes both in vitro and in vivo. $J$ Clin Invest 1996; 97: 1931-1941.

25. Metzner B, Barbisch M, Parlow F, Kownatzki E, Schraufstatter I, Norgauer J. Interleukin-8 and GRO alpha prime human neutrophils for superoxide anion production and induced upregulation of $\mathrm{N}$-formyl peptide receptors. $J$ Invest Dermatol 1995; 104: 789-791.

26. Laham N, Brennecke SP, Rice GE. Interleukin- 8 release from human gestational tissue explants: the effect of lipopolysaccharide and cytokines. Biol Reprod 1997; 57: 616-620.

27. Benveniste EN. Inflammatory cytokines within the central nervous system: sources, function and mechanism of action. Am J Physiol 1992; 263: C1-16.

28. Araujo DM, Cotman CW. Trophic effects of interleukin-4, -7 and -8 on hippocampal neuronal cultures: potential involvement of glial-derived factors. Brain Res 1993; 600: 49-55. 